\title{
Fostering micro-entrepreneurs' structural and relational social capital through microfinance
}

Ojong, Nathanael and Simba, Amon

\begin{abstract}
This paper uses a multi-dimensional perspective on social capital to investigate how a microfinance institution can enhance the social capital of poor entrepreneurs. Findings show that by creating an environment that encourages frequent meetings and interactions between borrowers, group-based microfinance facilitates the development of relational trust and expansion of the network size of micro-entrepreneurs. An increase in levels of structural and relational social capital, in turn, leads to numerous advantages in terms of the flow of a diversity of resources. Ensuring access to financial capital, creating an enabling environment that fosters structural and relational social capital, and providing training would constitute a much better approach to helping poor entrepreneurs.
\end{abstract}

Keywords: micro-entrepreneurs; relational social capital; structural social capital; microfinance; Cameroon

\section{Introduction}

With two billion people without access to formal financial services (Demirguc-Kunt et al. 2015), microfinance - the provision of a range of financial services, including business loans denominated in small amounts to segments of the population that formerly had no access to formal financial services (Bruton et al. 2015; Chen, Chang, and Bruton 2017; Servet 2015) - has generated substantial interest in a number of academic disciplines (Armendariz and Morduch 2010; Beisland, D’Espallier, and Mersland 2017; David and Sanyal 2017; Haldar and Stiglitz 2016; Hossein 2016; 
Servet 2006; Siwale 2016; Taylor 2012), including entrepreneurship (Bruton, Khavul, and Chavez 2011; Chen, Chang, and Bruton 2017; Chliova, Brinckmann, and Rosenbusch 2015; Kar 2013; Khavul 2010; Kent and Dacin 2013; Milanov, Justo, and Bradley 2015; Moss, Neubaum, and Meyskens 2015; Newman, Schwarz, and Borgia 2014; Shahriar, Schwarz, and Newman 2016).

While microfinance has grown into a global industry, estimated at US\$60-US\$100 billion (IFC 2014), a growing body of scholarship has generated mixed results, with respect to the impact of microfinance programs (Gu_erin, Labie, and Servet 2015; Kotir and Obeng-Odoom 2009; Mader 2015; Sanyal 2014). Although some scholars acknowledge the positive impacts of microfinance (e.g., Agbola, Acupan, and Mahmood 2017; Copestake, Bhalotra, and Johnson 2001; Dunn and Arbuckle 2001; Gonzalez 2008; Khandker 2005; McKernan 2002), including at country level (Raihan, Osmani, and Baqui Khalily 2017), others contest its so-called positive impact (e.g., Angelucci, Karlan, and Zinman 2015; Bateman 2010; Bateman, Maclean, and Galbraith 2017; Banerjee, Karlan, and Zinman 2015; Duvendack et al. 2011; Leinbach 2003; Stewart et al. 2010). Those in this category argue that microfinance has been detrimental to the poor (Butcher and Galbraith 2015; Servet 2015), caused the over-indebtedness of borrowers through multiple borrowing (Afonso et al. 2017; Ericksen, Ericksen, and Graham 2014; Guerin, Morvant-Roux, and Villarreal 2013), contributed to suicides (Mader 2013), strengthened patronage-driven practices (Guerin and Kumar 2017), and has led to the informalization of the local economy (Bateman 2014). Additionally, the exploitation of entrepreneurs' profits through high interest rates (Butcher and Galbraith 2015) and lack of management skills of the entrepreneurs (Evers and Mehmet 1994) have led many scholars to question the actual impact of microfinance. This current negative image of microfinance is problematic since it was conceptualized as a win-win solution for both 
microfinance institutions (MFIs) and their borrowers. Furthermore, to date, little emphasis has been placed on how microfinance provision can enhance borrowers' social capital.

In this environment of controversy and to address this gap in the literature, our study shows how microfinance provision can enhance the structural and relational social capital of microentrepreneurs, as well as highlight the benefits of increased levels of social capital.

We address a key question: how does an MFI increase levels of structural and relational social capital of its clients? We build upon extant scholarship by using qualitative data collected through semi-structured interviews with clients and employees of an MFI in Cameroon - a country that has received limited attention in entrepreneurship research.

Following Nahapiet and Ghoshal's (1998) multi-dimensional (structural and relational) framework of social capital, we show how group-based microfinance facilitates the expansion of borrowers' social networks and the development of ties which constitute crucial sources for information, financing, business opportunity identification, and advice. We indicate that some of the problems plaguing the microfinance industry can be remedied by designing microfinance programs that are beneficial to borrowers. If so, the controversy and skepticism surrounding microfinance calls for a case-by-case examination of its usefulness.

This study offers three primary contributions. First, we synthesize research conducted on microfinance from both entrepreneurship and other academic disciplines, including international development scholarship, in order to shed light on the importance of group-based microfinance to poor entrepreneurs. Given the interdisciplinary nature of the research, we seek to provide insights both for the international development community - which often conceptualizes the problem of poor entrepreneurs solely as a lack of financial capital - and the entrepreneurship community, which is gradually trying to understand the complexity of entrepreneurship in impoverished 
contexts. Second, we provide evidence of how group-based microfinance can enhance borrowers' social capital. In contrast to previous studies that have examined social capital as a unidimensional concept (e.g., Feigenberg et al. 2014; Mafukata, Dhlandhlara, and Kancheya 2017), we use a multidimensional conception of social capital to illustrate how group-based microfinance facilitates the expansion of borrowers' social networks and enhances the quality of ties between them. Specifically, we argue that through frequent group/center meetings and interactions, an MFI may increase levels of relational and structural social capital of its borrowers. Third, we suggest that the socioeconomic context in which MFIs are embedded, including the design of their programs, impacts entrepreneurial activity. We show how due to the low level of formal education and limited business skills, an MFI can make a significant difference by offering training and support to micro-entrepreneurs. Ensuring access to financial capital, creating an enabling environment that fosters structural and relational social capital, and providing training would constitute a much better approach to helping poor entrepreneurs. Taken together, these contributions provide a starting point for entrepreneurship scholars wrestling with the controversy and skepticism of microfinance, while they also offer practical implications for microentrepreneurs and policy-makers in low-income economies.

The rest of the paper is structured as follows: following a literature review of microfinance and social capital, a section on methodology is presented. We then present our findings regarding how an MFI can enhance borrowers' structural and relational social capital and highlight the role of training. Finally, we discuss the study's contributions and implications.

\section{Theoretical background}

Microfinance provision has attracted mainstream banks, for-profit investment funds, not-for-profit actors, insurance companies, mobile network operators (Bruton et al. 2015; Chen, Chang, and 
Bruton 2017; Shahriar, Schwarz, and Newman 2016), and, more recently, internet-based crowdfunding intermediaries (Allison et al. 2015; CGAP 2017). At present, a range of financial services, including insurance, debt and equity financing, and savings and retirement plans all fall under the canopy of microfinance when they are denominated in small amounts (Bruton et al. 2015). In low-income economies, many micro-entrepreneurs use microloans to seed their microenterprises (Bruton, Khavul, and Chavez 2011; Khavul 2010), since alternative sources of funding provided by family and friends (Collins et al. 2009) are limited, while conventional banks are reluctant to lend to the poor (Khavul, Chavez, and Bruton 2013). The fact that microfinance - as a form of entrepreneurial finance - focuses on financing the micro-enterprises of low-income populations (Chen, Chang, and Bruton 2017) renders it quite distinct from angel investing and venture capital, which usually target higher potential ventures (Chemmanur and Chen 2014; Cumming and Suret 2011).

MFIs use two lending models: individual and group lending. The group lending model emerged as a means for lending institutions to manage risk when clients have no formal collateral to secure loans (Milanov, Justo, and Bradley 2015). The underlying logic behind the group lending model is that individuals within a group can be considered ineligible to get microloans, but the group is creditworthy (Armendariz and Morduch 2010). Group lending purports to transfer the screening, monitoring, and enforcement of loans to the collective of borrowers (Armendariz and Morduch 2010; Chakravarty and Shahriar 2015; Chen, Chang, and Bruton 2017; Haldar and Stiglitz 2016). The group lending model aims to alleviate four major problems faced by MFIs that lend to low-income clients: to determine what kind of risks potential borrowers are in (adverse selection), to ensure that borrowers will use the loan properly once disbursed so that they will be able to repay (moral hazard), to learn how their projects really did should they declare their 
inability to repay (auditing), and to seek methods to force borrowers to repay their loans if they are reluctant to do so (enforcement) (Ghatak and Guinnane 1999).

Peer monitoring, whereby group members observe one another's activities (Haldar and Stiglitz 2016), enables group members to verify the project returns of each other, hence, tackle ex-post moral hazard. MFIs tend to use individual liability or group liability (de Quidt, Fetzer, and Ghatak 2016; Giné and Karlan 2014). In the former, a single borrower assumes the entire liability for repayment (Chen, Chang, and Bruton 2017), while in the latter, group members are expected to repay the loans of their unsuccessful members (de Quidt, Fetzer, and Ghatak 2016). Thus, there is an incentive for group members to monitor the projects of one another to ensure that the loan is properly used to avoid repayment default. Additionally, group-based microfinance programs often rely on frequent interactions between loan officers and borrowers through regular visits and group meetings (Siwale 2016).

Scholars have sought to understand how microfinance can contribute to entrepreneurial activity (Bruton, Khavul, and Chavez 2011; Chliova, Brinckmann, and Rosenbusch 2015; Newman, Schwarz, and Borgia 2014) by examining the performance of MFIs as lenders and the performance of entrepreneurs as borrowers (Chen, Chang, and Bruton 2017). The impact of microfinance on borrowers is crucial in low-income and emerging economies where poor entrepreneurs face numerous barriers to access resources required to establish new ventures (Ahlstrom and Ding 2014). Microfinance scholars have shown that in such impoverished settings, group-based microfinance can enhance borrowers' social networks (Feigenberg et al. 2014). Through social networks, poor entrepreneurs have access to advice, business opportunities, role models, and customer referrals (Gao, Liu, and Qian 2016; Zafar, Yasin, and Ijaz 2012). 
Although social capital has been conceptualized in a number of ways, the essential idea is that it symbolizes the value embedded in the social relationships of individuals or social units (David and Sanyal 2017; Gedajlovic et al. 2013; Gironde 2007; Jack 2005; Jonsson and Lindbergh 2013; Mafukata, Dhlandhlara, and Kancheya 2017; Sanyal 2009; Tubadji, Kourtit, and Nijkamp 2014); that is, 'the aggregate of the actual or potential resources which are linked to possession of a durable network of more or less institutionalized relationships of mutual acquaintance or recognition' (Bourdieu 1986, 248).

Since entrepreneurship entails opportunity identification, evaluation, and exploitation (Shane and Venkataraman 2000), the social capital intrinsic in networks facilitates an entrepreneur's access to information; hence, social capital fosters opportunity identification (Tang 2010).

In contrast to studies that have examined social capital as a unidimensional concept (e.g., Feigenberg et al. 2014; Mafukata, Dhlandhlara, and Kancheya 2017), Nahapiet and Ghoshal (1998) advance a multidimensional conceptualization of social capital: cognitive, structural, and relational. Crucially, such a multi-dimensional conception recognizes and distinguishes social capital in its multiple forms (Gedajlovic et al. 2013). The structural and relational dimensions of social capital - which are of relevance to this paper - draw on Granovetter's (1992) structural and relational embeddedness. He argues that in economic exchange, 'most behavior is closely embedded in networks of interpersonal relations' (Granovetter 1985, 504). Granovetter's argument distinguishes and emphasizes the unique roles that both "concrete personal relations and structures (or "networks") of such relations' play in the daily work and accomplishments of all kinds of economic players $(1985,490)$.

Structural dimension of social capital refers to 'the overall pattern of connections between actors - that is, who you reach and how you reach them' (Burt 1992, cited in Nahapiet and Ghoshal 
1998, 244). A general principle is that the different positions in a social network influence resource flows, hence affecting the amount and variety of resources (Burt 1992; Jonsson and Lindbergh 2013). Critical to this dimension are features such as connectivity, centrality, and hierarchy, along with network ties between actors (Nahapiet and Ghoshal 1998; Wasserman and Faust 1994). Network ties constitute information vehicles that reduce the amount of time and investment needed to gather information (Nahapiet and Ghoshal 1998; Tang 2010), and these information benefits occur in three forms: access, timing, and referrals (Burt 1992). These information advantages enhance the survival, performance, and growth potential of new ventures (Boden and Nucci 2000; Cable and Shane 1997). Therefore, the network structures represent facets of social capital that influence the variety of opportunities available to micro-entrepreneurs in terms of business opportunities, advice, funding, etc. Moran (2005) contends that the advantages of structural social capital are enhanced by network size. Group-based microfinance may facilitate the expansion of the network size of micro-entrepreneurs.

The relational dimension of social capital refers to personal relationships developed through a history of interactions with people in a social network (Granovetter 1992). Nahapiet and Ghoshal define relational embeddedness as the 'personal relationships people have developed with each other through a history of interactions' $(1998,244)$. Key facets of the relational dimension of social capital include trust, reciprocity, overlapping identities, commitment, and feelings of closeness (Granovetter 1985; Moran 2005). Relational trust refers to a trustor's belief that a trustee will not act opportunistically because the trustee cares about the trustor's welfare (Rousseau et al. 1998). Consequently, relational trust improves information flows and decreases information asymmetries (Jonsson and Lindbergh 2013; Rowley, Behrens, and Krackhardt 2000). Therefore, relational 
social capital paves the way for micro-entrepreneurs to receive 'informational, physical and emotional support in the venture creation process' (Liao and Welsch 2005, 350).

By encouraging participation and involvement, group-based microfinance programs can lead to greater structural and relational social capital between clients (Newman, Schwarz, and Borgia 2014). Arguably, micro-entrepreneurs who participate in group lending could enjoy the diverse advantages reserved for people embedded in a social network.

Although structural and relational social capital are crucial to the success of micro-enterprises, scholars (e.g., Datar, Epstein, and Yuthas 2008; Sayinzoga, Bulte, and Lensink 2016; Zhuang et al. 2009) have argued that the role of training cannot be neglected. Berge, Bjorvatn, and Tungodden (2011) find that the lack of business knowledge and skills is a significant constraint to entrepreneurial success. Training is of particular relevance to micro-entrepreneurs in impoverished settings who may not be equipped with sufficient education and skills to develop their microenterprises (Radhakrishnan 2015) or surmount barriers to innovation (Bradley et al. 2012). This lack of skills, in turn, can encourage micro-entrepreneurs to remain 'static' rather than grow their ventures. Karlan and Valdivia (2011) find business knowledge improvement among clients who received business training.

\section{Methodology}

\section{Locating the study}

Given our approach, it is essential to describe our context (Pratt 2009). Cameroon is a low-income country with a total population of 23 million inhabitants. It has a GDP per capita of \$1217 (current US\$) and a Gini index of 46.5 (World Development Indicators 2015), which indicates a relatively high dispersion between the poor and the wealthy in the country. About $37.5 \%$ of the population 
lives below the national poverty line of 931 CFA Franc (US\$1.60) per day (NIS 2015a). It has a labor force of approximately 8.42 million. Based on estimates, unemployment among those aged between 15 and 35 is at $13 \%$, but crucially, underemployment is at $71.9 \%$ at the national level and $54.4 \%$ and $79.2 \%$ in urban and rural zones, respectively (AfDB 2012). Informal employment stands at $88.6 \%$ (NIS 2015b). Most micro-enterprises in the country opt to operate in the informal economy due to the administrative hurdles to license a business but also for the avoidance of taxes and other legal requirements, such as social security. Similarly, most clients of MFIs that run micro-enterprises fail to register and obtain a license.

The Cameroonian microfinance market is divided among four main types of service providers: specialized MFIs, credit unions, village banks, and non-governmental organizations. According to Cameroon's Ministry of Finance, 412 MFIs were authorized to operate in the country. Cameroonian MFIs are divided into three categories. The first category comprises institutions that collect deposits from members to be used for loans exclusively to those members. The second category is made up of institutions that receive deposits and grant loans to third parties. The third category comprises credit-only MFIs that do not collect deposits. MFIs account for about $15 \%$ of credit provided by the financial sector in the country.

This study focused on clients of an MFI that uses the solidarity group lending model. This MFI operates in Mezam and Boyo, which are administrative divisions situated in the North-West Region of Cameroon. Boyo is primarily a rural area, while Mezam is comprised of both urban and rural areas. Established in 1998, this MFI has a history of providing loans to micro-enterprises. It serves over 1500 clients whose loans range between 50,000 CFA Franc (US\$86) and 600,000 CFA Franc (US\$1041). Most of its clients are women. In 2010, 114 million CFA Franc (US\$197,803) was granted as loans, up from 90 million CFA Franc (US\$156,165) the previous year. As of 
December 2017, it had granted about 465 million CFA Franc (US\$840,828). Loans have been invested in food cultivation, motorcycle taxis, poultry, pig and goat farming, restaurants, tailoring and embroidery, etc.

Borrowers form groups made up of five people. Once a group is formed, members attend a two-day training session that covers issues related to business administration, financial literacy, marketing, lending policies, and procedures. Clients also receive additional training periodically.

\section{Method adopted}

A qualitative lens was adopted to examine how group-based microfinance may foster microentrepreneurs' structural and relational social capital. Such an approach was appropriate because our objective was to address the 'how' rather than 'how many' question and 'articulating processes' (Pratt 2009, 856) of structural and relational social capital among micro-entrepreneurs. Also, we adopted a qualitative approach (Neergard and Ulhøi 2007) as it allowed for a more detailed and richer analysis of structural and relational social capital in ways not possible through quantitative research. Such an approach can facilitate the development of a better understanding of the subject matter (Denzin and Lincoln 2011), extend existing theory, and develop new theoretical explanations for noticed phenomena (Lee 1999). This approach is especially pertinent to our research as it 'enables the researcher to enter and explore with the respondent his or her phenomenal world and the cognitive frameworks that come to bear, and ultimately, to learn the respondent's point of view' (Sackmann 1991, 305). Our fieldwork was conducted in 2011 over several months. We conducted semi-structured interviews with clients and employees of an MFI. As the aim of our study is to examine how group-based microfinance enhances microentrepreneurs' structural and relational social capital, face-to-face semi-structured interviews were 
considered well suited to achieve this aim because it allowed us to capture the dynamics of social capital and microfinance.

\section{Sampling}

We selected respondents from Mezam and Boyo, as they are regions that capture the rural-urban dynamics, which are vital to our study regarding the fostering of structural and relational social capital among micro-entrepreneurs. Our choice of the research site was also guided by the intention of one of the authors to benefit from their knowledge of local language and culture (Sanyal 2009). We purposefully sampled (Pratt 2009), selecting an MFI that uses the group-based lending model since their clients would provide experiences appropriate for the study. This MFI, due to its groupbased lending model, seemed to offer an ideal environment to study their borrowers' structural and relational social capital. The MFI has centers made up of several groups. From each group, we selected respondents who had obtained a loan and were willing to have an interview. The same process was done in both rural and urban zones to capture diversity. Such sampling does not allow the generalization of results to the entire population, but findings may be generalized at a conceptual level (Jack, Drakopoulou, and Anderson 2008). Forty-six borrowers agreed to be interviewed, and we also interviewed five employees of the MFI. Interviewing MFI employees also made it possible to corroborate the narratives of the borrowers.

\section{Data collection}

One author's established relationship with the management of this MFI facilitated research access to their clients and employees. We were allowed to attend group meetings in the presence of loan officers. We hoped that access to their borrowers would enable us to investigate how group-based microfinance fosters structural and relational social capital. 


\section{Interviews}

A total of 51 face-to-face semi-structured interviews with borrowers (46) and employees (5) of the MFI were completed. The five MFI employees interviewed included a manager, an accountant, and three loan officers. The interviews lasted no more than 90 minutes and were recorded and transcribed. Interviews were recorded using a digital voice recorder and we took notes by hand. Field notes were useful in recording visual data that might otherwise have been lost if we had solely relied on the digital voice recorder, while the digital voice recorder provided detailed recorded talk that field notes alone could not have provided (Silverman 2010). Some follow-up telephone interviews were conducted to get additional information on issues that were missed during the first interviews (Taylor 1984). The interviews were organized around the research question and themes of the study. To facilitate the disclosure of information, it was made clear to participants that the information they provided would not be passed on to any third party and would be anonymized. Selected participants were proficient in English and/or Pidgin (the most commonly spoken local language). A translator was not needed as one of the study's authors, who conducted the interviews, is also proficient in Pidgin. Interviews started with initial questions and then with follow-up probes depending on the initial responses. This helped to ensure that the respondent was not being influenced to respond in a particular way and confirmed that information gathered from participants mirrored the actual situation (Jack 2005).

Some interviews were conducted independently in private areas at the branch offices of the MFI (ensuring there was no monitoring by MFI staff in order not to influence responses). Other interviews were conducted at respondents' homes and places of business.

The respondents had diverse demographic and socioeconomic characteristics. Women constituted $41.3 \%$ of participants, while men made up $58.7 \%$. Fifty percent of respondents lived 
in rural areas, and 50\% were urban residents. A significant proportion (71.7\%) had primary level education, $19.6 \%$ had secondary level education, $2.2 \%$ held a university degree, and $6.5 \%$ had no formal education. Most respondents (34.8\%) were aged 45-54, while the minority $(15.2 \%)$ were between the ages of 20 and 34 . While $24 \%$ of participants fell in the 35-44 age band, those aged 55 and above constituted $26 \%$. Regarding their marital status, $4.3 \%$ were single, $80.4 \%$ were married, $2.3 \%$ were widows, and $2.3 \%$ were divorced.

\section{Analysis technique}

Our analysis explored themes in the responses of participants using a comparative method (Glaser 1978; Silverman 2010). Data collected were sorted before analysis could begin. The sorting process meant interviews conducted in Pidgin were translated into English by one of the authors, and all interviews were transcribed. Sorting raw data into categories (Eisenhardt 1989) made it possible to identify ideas that are divergent. Interviews were read several times and emerging concepts were grouped into categories using open coding (Corbin and Strauss 2008) to develop first-order concepts. Wherever possible, we used participants' language to label in vivo codes. First-order concepts were subsequently categorized into second-order themes (Corley and Gioia 2004; Pratt 2009). NVivo 8.0 assisted our analysis, enabling movement around free nodes, tree nodes, and within tree nodes (Bazeley 2007). We sliced the data by asking questions such as who, what, when, where, and how, and by using theoretical memos (Bazeley 2007; Corbin and Strauss 2008). We connected themes that have a meaningful relationship and compared emerging themes with extant scholarship. These analytic strategies of asking questions and making comparisons are considered key analytical tools for elaborating the analysis (Corbin and Strauss 2008). 
As noted earlier, the structural and relational dimensions of social capital are critical to microentrepreneurs. Therefore, we seek to answer a major research question: how may an MFI facilitate an increase in levels of structural and relational social capital of it clients?

\section{Results}

The findings are presented in three sections, representing structural social capital, relational social capital, and the role of training. The different sections present the value of training and how groupbased microfinance enhances the relational and structural social capital of micro-entrepreneurs.

\section{Fostering micro-entrepreneurs'structural social capital}

The borrower's (micro-entrepreneur) network evolves from a configuration that is high in cohesion (i.e., lending group of five people) towards a more sparse network (made up of borrowers from other lending groups who attend the same center meetings). A group is typically made up of five people and the groups are organized into centers. Centers, in turn, are made up of eight groups, which are about forty clients. Therefore, the center meetings, which are organized once a month, render it possible for each member of a group to have access to about 35 other borrowers from the different groups.

Structural social capital, in turn, makes it possible for micro-entrepreneurs to have leads and access to market information. This information is vital, especially to those involved in poultry farming and agricultural activities. Some members became aware of new markets to sell their products at a higher price in order to increase their profit margins. In this study, access to market information is crucial, particularly to clients in rural areas, as access to external markets remains a major challenge. Informational benefits, enhanced by network size, enabled micro-entrepreneurs to have access to 'new markets,' thereby increasing their profit margin. As summarized by a 
participant, 'I was running a toothbrush business in Douala, and I finally ended up in Bertoua [because] the business was very profitable [there]. It was a good business; I generated an income of about 700,000CFA Francs [US\$1,263] in three months’' (Interview 42).

The study revealed that centers are also characterized by weak ties (Granovetter 1973) or structural holes (Burt 1992). The center, as a network of contacts, is characterized by weak ties because the different groups, from the various communities, meet just once a month. Thus, there are not regular interactions. This sparse social network, however, has informational advantage in terms of the discovery of business opportunities. For example, as one participant stated, 'A certain person told me to stop my current business [because] it was not profitable... he showed me where he usually buys the merchandise [plastic bags]. I sold it [plastic bags] and had about 120,000CFA Franc [US\$216] after a month' (Interview 42). This indicates that weak ties play a crucial role too. Moran $(2005,1133)$ stresses that, '[T] he less one's contacts know and interact with each other, the more likely the information and knowledge available to these contacts will be non-redundant.' As one's contacts at a center do not interact with each other on a frequent basis, it gives the microentrepreneur access to more diverse information. Whether it takes the form of new business opportunities, new markets to sell their products, or alternative sources of finance, the information's non-redundancy makes it more valuable as it positions members to learn of information sooner, thereby creating an advantage over others who do not have access to this information.

Consistent with previous research findings (e.g., Burt 1992; Walker, Kogut, and Shan 1997), the different positions in the social network (made up of borrowers from different groups) influence resource flows, thereby affecting the amount and variety of resources available to microentrepreneurs. The interviews indicate that the amount and diversity of resources (including gifts) 
available to a person depends on their position in the network. For example, regarding the provision of material assistance to others, a participant said, 'I prepare a meal for a person who is located on my eyes and buy soap for a person situated on my nose' (Interview 7). Though these bodily features are all located on the face - an 'external part that is the most suggestive or expressive of one's inner world' (Yu 2008, 251) - the eyes are regarded as more important than the nose. In our local context, a meal is more valuable than a piece of soap. This difference in terms of the quality of assistance provided to people facing a similar situation is indicative of the strength of ties (i.e., weak versus strong ties).

\section{Fostering micro-entrepreneurs' relational social capital}

Consistent with existing literature (e.g., Bourdieu 1986; Du, Guariglia, and Newman 2015), relational social capital in lending groups is fostered through investment in time and money. In our study, the MFI facilitates social interaction between borrowers of a group through group meetings organized at least once every two weeks. So, group members meet at least 24 times per year. Additionally, loan officers encourage group members to have meetings outside of the regular group meetings to discuss issues related to their businesses. Most of the meetings take place at members' homes. Based on observation, this informal setting is ideal for social interaction and facilitates the building of closeness and solidarity between group members. Usually, members discuss their businesses and other issues in their daily lives.

The findings suggest that regular interactions develop relational trust. Relational trust, in turn, reduces information asymmetries. For example, one participant expressed, 'Normally, in life, when one interacts with people, one knows those who are truthful and those who are not. Interactions enable one to gather information about a person, so you know the person you are dealing with' (Interview 39). 
Borrowers also indicated that regular interactions are facilitated by spatial proximity. In our local context, spatial proximity paves the way for developing personal relationships - the quintessence of relational social capital. Regarding the importance of spatial proximity, a participant noted that, 'If I reside with a person in the same community, I will know about the person's behaviour' (Interview 44).

In our study, the strong bond developed between micro-entrepreneurs of a lending group, as a result of the regular interactions promoted by the MFI, gives microentrepreneurs access to diverse resources in the form of business opportunity identification, ideas, financial capital, customer relationship building strategies, and leads. For example, the MFI has a policy of not giving borrowers multiple loans. During peak seasons, such as in December, clients are usually in need of additional loans to buy more goods to meet market demand. Micro-entrepreneurs leverage their relational capital to get loans from other sources. As stated by a participant, 'I obtain a loan from social groups because it isn't easy to borrow money from the [MFI] when there is an outstanding loan' (Interview 13). This finding supports the study by Batjargal (2003), who found that networks help entrepreneurs mobilize resources.

Additionally, group members in the nascent stages of the entrepreneurial process learn from those with existing ventures about building relationships with customers. Regarding relationship development with customers, a participant maintains that, 'You have to smile with your customers; you approach a customer who comes to your business place with a smile so that the customer can come back next time' (Interview 31). This customer retention strategy may seem obvious to people in advanced economies; however, this is valuable to micro-entrepreneurs in impoverished contexts, particularly due to the low level of formal education. As noted earlier, $71.7 \%$ of respondents in our study have only a primary level education. So, this is valuable information to 
such people, especially those in rural areas. Skinner, Moss, and Parfitt (2005) note in their study that approaching customers with a smile constitutes one of the principal factors that prompt subsequent visits.

Interestingly, the possibility of sharing business ideas was one of the reasons why some microentrepreneurs became clients of the MFI. One participant explained that, 'I decided to be a client [of the MFI] because of my desire to be among people and exchange ideas' (Interview 38). Some group members started 'joint micro-enterprises' as a result of the exchange of ideas with other members. One participant described establishing a joint business with another group member:

Interviewer: What was the amount of loan given to you?

Interviewee 20: It was 220,000CFA Franc [US\$381]

Interviewer: What did you do with this loan?

Interviewee 20: I established a joint business with a group member.

Interviewer: What type of business?

Interviewee 20: It was a motorbike taxi business.

Interviewer: What was the cost of the motorbike?

Interviewee 20: It was 500,000CFA Franc [US\$865]. His [group member] loan was 200,000CFA Franc [US\$346], so we raised the remaining amount.

The excerpt above suggests that relational trust - fostered through frequent group meetings and interactions - encourages cooperation among borrowers. This corroborates the point that strong ties foster cooperation (Uzzi 1997) and reduce opportunistic behavior (Nahapiet and Ghoshal 1998). The exchange of ideas encourages cooperation between borrowers.

\section{Provision of training and support to borrowers}

As indicated earlier, the MFI provides training to borrowers. The provision of training and support is vital in this impoverished context since micro-entrepreneurs, especially those in rural areas, have 
limited business skills and a majority $(71.7 \%)$ have received only a primary level education. The findings suggest that borrowers who receive training recognize the value it brings to their businesses. The responses of participants 1 and 41 are typical:

Interviewer: Tell me about the training you received.

Interviewee 1: The training helped me. Training was provided on how to run our businesses. I can say that it is as a result of the training that I know how to handle the business well. They [MFI] covered several areas, such as business administration and financial literacy. I thank God for the training because I can say that's what has been sustaining me.

Interviewer: What was the loan used for?

Interviewee 1: In my first year [1997] as a client [of the MFI], I received a loan of 15,000CFA Franc [US\$26]. I used it for farming; I planted yams. I harvested the yams and sold it, and that first year, I was the highest saver [at the centre]. That enabled me to buy a sewing machine for my tailoring business. Then, I took another loan of 200,000CFA Franc [US\$346] and paid it back.

Similarly, the following excerpts indicate the positive role of training to successful microfinancing:

Interviewer: Tell me about the state of your business.

Interviewee 29: To be sincere, the business is profitable. We received training; it has been instrumental in the growth of the business. I now have a second poultry farm. I'm able to meet the needs of my household, as well as send my children to college without requiring financial assistance from my husband...I have been saving income generated from the business on a regular basis. I currently have savings of about 300,000CFA Franc [US\$520].

Another participant agrees with this narrative regarding the support provided by the MFI:

Interviewer: Why did you decide to be a client of this MFI?

Interviewee 41: I became a client because they give loans but, more importantly, they encourage us to save and they follow-up with our businesses. When I became a client, I was 
more interested in getting the loan, but I realised that they follow-up with my business, which ensures that the business runs well.

This information is corroborated by information gathered from the loan officers. For example, one of the loan officers states the following, 'I visit their business places...I visit the farms to know about the state of their businesses. I provide advice on how to improve their business activities in order to generate more income.' For some micro-entrepreneurs, the training and support provided are even more important than the size of the loan. This indicates that although start-up capital is essential, the provision of training and support also seem to be significant in determining the direction a micro-enterprise may take. Interviewee 8 spoke to this idea:

Interviewer: Were you granted the loan amount you requested?

Interviewee 8: The loan was sufficient because the MFI does not just provide loans, they also provide training. If you are given a small amount, and you follow the training, you will make progress with the loan that has been given to you. It's better than giving you a big loan without training.

Although the provision of training is recognized as one of the principal drivers of successful microfinancing, the findings suggest another vital driver: diversification of income generating streams. This is exemplified in the following comments by a participant:

Interviewer: How much was your first loan?

Interviewee 11: I was given 20,000CFA Franc [US\$35]

Interviewer: What did you do with the loan that was given to you?

Interviewee 11: It was used to buy pesticides for my vegetable garden.

Interviewer: Since then have you taken another loan?

Interviewee 11: Yes, I'm almost going for the fifth loan. The second loan was 45,000CFA Franc [US\$78].

Interviewer: So how much was your most recent loan? 
Interviewee 11: 400,000CFA Franc [US\$692]. Now I'm going for pepper production, I want to plant at least 20,000 plants. I have already planted about 4000; that's my new project. Regarding the second project - by June - I will be going for rice production, so I have to start preparing now. At present, I'm growing vegetables which could be sold at any time. I intend to use the next loan to purchase a vehicle to facilitate the transportation of farm produce. I intend to apply for a 500,000CFA Franc [US\$865] loan.

Another participant echoes the importance of multiple income generating streams to successful micro-financing:

Interviewer: Tell me about the training you received.

Interviewee 14: It has been very helpful. It helped me in terms of improving my ideas concerning the way to grow the business. In addition to the pig and vegetable farming, I used part of the loan to employ some people to work on the sand business, so the sand business generated a quick profit. Then, I used part of the profit to purchase feed [for the pigs]. So, I do not experience financial difficulties because I do not depend solely on the pig farming. I wouldn't have had it easy if I depended solely on pig farming.

The findings suggest that the provision of training is crucial to micro-entrepreneurs in impoverished settings. Interestingly, of the three loan officers interviewed, two had a high school diploma, and one had a Diploma in Cooperative Management in addition to a high school diploma. Thus, this suggests that local microfinance professionals without a business-related university degree can also play a significant role in terms of the provision of basic training and support to micro-entrepreneurs. Indeed, a recent study found that loan officers with lesser education find it easier to interact with the poor (Siwale 2016). Their mastery of the local context is an advantage.

\section{Discussion and conclusion}

This paper has examined how group-based microfinance can help foster microentrepreneurs' structural and relational social capital and how enhanced social capital, in turn, leads to many 
advantages in terms of the flow of a diversity of resources to microentrepreneurs. Several studies have contested the positive impact of microfinance (e.g., Afonso et al. 2017; Angelucci, Karlan, and Zinman 2015; Bateman 2010; Bateman, Maclean, and Galbraith 2017; Banerjee, Karlan, and Zinman 2015; Duvendack et al. 2011; Stewart et al. 2010). However, we argue that in examining the impact of microfinance, it is crucial to take into consideration the institutional design and local context; therefore, it is necessary to examine the usefulness of microfinance on a case-by-case basis. Thus, this paper suggests a more nuanced point of view and highlights the role of groupbased microfinance in fostering micro-entrepreneurs' structural and relational social capital through its lending methodology. By bringing together groups from different communities, the MFI enhances their clients' network sizes. An increase in contacts develops more channels for obtaining valued information and resources (Emerson 1962). Emphasizing this point, Burt (1992, 16) notes that 'bigger is better,' but adds that 'size is a mixed blessing.' This means that an MFI that uses the group lending approach would have to keep the center (network) to a manageable size so that borrowers' contacts do not become colossal, as this could be difficult to manage. Also, network ties - between borrowers of different groups - established as a result of these center meetings reduce the amount of time and investment needed to gather information (Nahapiet and Ghoshal 1998). The presence of weak ties (Granovetter 1973) or structural holes (Burt 1992) in these center meetings increases the efficiency of information diffusion vital to the entrepreneurial activities of the borrowers of the MFI.

This paper also argues that though the center is characterized by weak ties, its diversity is a source of strength. Burt (1992) contends that people in networks characterized by diversity benefit from more diverse information; therefore, there are more information advantages that occur in terms of access, timing, and referrals. The value of weak ties stems from their greater inclination 
to bridge otherwise disconnected groups. This increases the likelihood that such ties would serve as channels carrying more information that is likely to be unique, thereby more valuable (Burt 1992).

The finding that networks facilitate business opportunity identification supports Bhagavatula et al.'s (2010) findings that personal networks can facilitate business opportunity recognition. However, scholars have warned that the benefits of network membership should not be taken for granted. Studies have argued that people with lower status may find it difficult to take full advantage of network membership (Ridgeway and Smith-Lovin 1999). Additionally, the findings show that 'a given contact can vary in their accessibility to others depending on who the seeker is to others;' therefore, an individual may have 'time for high-status people, but not for others' (Borgatti and Cross 2003, 435). These multiple 'melodies' within networks influence the quality of resources that flow between those in the network.

Our findings indicate that by encouraging frequent interactions between borrowers of a group, an MFI facilitates the gathering of information which, in turn, enhances their relational social capital. Information and experience allow parties to evaluate trustworthiness (Goodman 2017; Nooteboom 2002), and this knowledge and experience gained through interactions makes it possible for trust 'to take root' (Coriat and Guennif 1998, 54). While acknowledging that trust may also precede experience (Welter 2012), others argue that 'a trust-based relationship will only survive if it is supported by experience' (Coriat and Guennif 1998, 54).

Additionally, this paper contributes to the literature at the interface between entrepreneurship and microfinance by suggesting that successful entrepreneurship in impoverished contexts entails a combination of financial capital, structural and relational social capital, training, and support. The findings suggest that micro-entrepreneurs with lesser formal education seem to value the 
training and support provided by the MFI. Consequently, our results support the findings from previous studies (e.g., Berge, Bjorvatn, and Tungodden 2011; Datar, Epstein, and Yuthas 2008; Sayinzoga, Bulte, and Lensink 2016; Zhuang et al. 2009) that have argued in favor of the integration of training into microfinance programs.

\section{Practical implications}

Studies have sought to comprehend how microfinance can contribute to entrepreneurial activity (Bruton, Khavul, and Chavez 2011; Chen, Chang, and Bruton 2017; Chliova, Brinckmann, and Rosenbusch 2015; Newman, Schwarz, and Borgia 2014). Our findings reveal that MFIs can play a significant role not only by providing financial capital to microentrepreneurs but also by creating the enabling environment that enhances their structural and relational social capital. Mindful of the numerous barriers that poor entrepreneurs face in terms of having access to resources to create new ventures (Ahlstrom and Ding 2014), the diversity of benefits of an increase in levels of structural and relational social capital (for example, advice, business opportunities identification, role models, customer referrals, funding, etc.) cannot be minimized. Therefore, if MFIs really want to play a significant role in the economic lives of poor entrepreneurs, it is vital to design microfinance programs that would serve as enablers in terms of the development of borrowers' social capital.

Additionally, the provision of training to borrowers represents an important topic (Datar, Epstein, and Yuthas 2008; Sayinzoga, Bulte, and Lensink 2016). Our findings reveal not only the vital role of training and support in entrepreneurial activity in impoverished settings but also the significant role played by loan officers with lesser education in providing training and support. The crucial role played by loan officers with lesser education in providing training suggests that MFIs do not necessarily need to rely on international staff for the delivery of training to poor 
entrepreneurs in the Global South. Well-trained local staff can offer training that would be valued by micro-entrepreneurs. This also has cost implications since relying on local professionals will reduce the MFI's operating costs. The fact that micro-entrepreneurs value the training provided by the MFI is indicative of the gap in entrepreneurial skills and knowledge in low-income economies. As entrepreneurial learning is vital to advancing knowledge on entrepreneurship (Wang and Chugh 2014), it is therefore vital for policy-makers to promote entrepreneurship in their country's educational system. Additionally, policy-makers could make use of successful microentrepreneurs as role models. Zozimo, Jack, and Hamilton (2017) show the significance of learning from role models in different social settings. As a result, successful micro-entrepreneurs should be invited to play a role in entrepreneurial learning.

\section{References}

Afonso, J., S. Morvant-Roux, I. Gu_erin, and D. Forcella. 2017. "Doing Good by Doing Well? Microfinance, Self-Regulation and Borrowers' Over-indebtedness in the Dominican Republic." Journal of International Development 29 (7): 919-935.

AfDB (African Development Bank). 2012. "African Economic Outlook 2012: Promoting Youth Employment." Accessed 9 February 2017. www.africaneconomicoutlook.org/sites/default/ files/contentpdf/AEO2012_EN.pdf

Agbola, F., A. Acupan, and A. Mahmood. 2017. "Does Microfinance Reduce Poverty? New Evidence from Northeastern Mindanao, the Philippines." Journal Rural Studies 50: 159-171.

Ahlstrom, D., and Z. Ding. 2014. "Entrepreneurship in China: An Overview." International Small Business Journal 32 (6): 610-618.

Allison, T., B. Davis, J. Short, and J. Webb. 2015. "Crowdfunding in a Prosocial Microlending Environment: Examining the Role of Intrinsic Versus Extrinsic Cues." Entrepreneurship Theory \& Practice 39 (1): 53-73.

Angelucci, M., D. Karlan, and J. Zinman. 2015. "Micro-Credit Impacts: Evidence from a Randomized Micro-Credit Program Placement Experiment by Compartamos Banco." American Economic Journal: Applied Economics 7: 151-182.

Armendariz, B., and J. Morduch. 2010. The Economics of Microfinance. Boston, MA: MIT Press. 
Banerjee, A., D. Karlan, and J. Zinman. 2015. "Six Randomized Evaluations of Micro-Credit: Introduction and Further Steps." American Economic Journal: Applied Economics 7 (1): 1-21.

Bateman, M. 2010. Why Doesn't Microfinance Work? The Destructive Rise of Local Neoliberalism. London: Zed Books.

Bateman, M. 2014. "South Africa's Post-Apartheid Microcredit-driven Calamity." Law, Democracy and Development 18: 92-135.

Bateman, M., K. Maclean, and J. K. Galbraith. 2017. Seduced and Betrayed: Exposing the Contemporary Microfinance Phenomenon. Albuquerque: University of New Mexico Press.

Batjargal, B. 2003. "Social Capital and Entrepreneurial Performance in Russia: A Longitudinal Study." Organization Studies 24: 535-556.

Bazeley, P. 2007. Qualitative Data Analysis with NVivo. London: Sage Publication.

Beisland, L., B. D’Espallier, and R. Mersland. 2017. "The Commercialization of the Microfinance Industry: Is There a 'Personal Mission Drift' Among Credit Officers?' Journal of Business Ethics 1-16. doi:10.1007/s10551-017-3710-4

Berge, L., K. Bjorvatn, and B. Tungodden. 2011. "Human and Financial Capital for Microenterprise Development: Evidence from a Field and Lab Experiment." NHH Dept. of Economics Discussion Paper 1/2011. Oslo: Norwegian School of Economics.

Bhagavatula, S., T. Elfring, A. van Tilburg, and G. van de Bunt. 2010. "How Social and Human Capital Influence Opportunity Recognition and Resource Mobilization in India's Handloom Industry." Journal of Business Venturing 25: 245-260.

Boden, R., and A. Nucci. 2000. 'On the Survival Prospects of Men's and Women's New Business Ventures.” Journal of Business Venturing 15 (4): 347-362.

Borgatti, S., and R. Cross. 2003. "A Relational View of Information Seeking and Learning in Social Networks.” Management. Science 49: 432-445.

Bourdieu, P. 1986. "The Forms of Capital." In Handbook of Theory and Research for the Sociology of Education, edited by J. G. Richardson, 241-258. New York: Greenwood.

Bradley, S., J. McMullen, K. Artz, and Edward M. Simiyu. 2012. "Capital is Not Enough: Innovation in Developing Economies.” Journal of Management Studies 49 (4): 684-717.

Bruton, G., S. Khavul, and H. Chavez. 2011. "Microlending in Emerging Economies: Building a New Line of Inquiry from the Ground Up." Journal of International Business Studies 42 (5): 718-739.

Bruton, G., S. Khavul, D. Siegel, and M. Wright. 2015. "New Financial Alternatives in Seeding 
Entrepreneurship: Microfinance, Crowdfunding, and Peer-to-Peer Innovations." Entrepreneurship Theory \& Practice 39 (1): 9-26.

Burt, R. 1992. Structural Holes: The Social Structure of Competition. Cambridge, MA: Harvard University Press.

Butcher, W., and J. Galbraith. 2015. "Microfinance Control Fraud in Latin America." Forum for Social Economics 1-23. doi: 10.1080/07360932.2015.1056203

Cable, D., and S. Shane. 1997. "A Prisoner's Dilemma Approach to Entrepreneur-Venture Capitalist Relationships.” Academy of Management Review 22 (1): 142-176.

CGAP (Consultative Group to Assist the Poor). 2017. "Crowdfunding and Financial Inclusion." Accessed 15 April 2017. http://www.cgap.org/sites/default/files/Working-Paper-Crowdfund ing-and-Financial-Inclusion-Mar-2017.pdf

Chakravarty, S., and A. Shahriar. 2015. "Selection of Borrowing Partners in Joint Liability-Based Microcredit: Evidence from Framed Field Experiments in Bangladesh." Entrepreneurship Theory and Practice 39 (1): 129-144.

Chemmanur, T., and Z. Chen. 2014. "Venture Capitalists Versus Angels: The Dynamics of Private Firm Financing Contracts.” Review of Corporate Finance Studies 3 (1-2): 39-86.

Chen, J., A. Chang, and G. Bruton. 2017. "Microfinance: Where Are We Today and Where Should the Research Go in the Future?" International Small Business Journal 35 (7): 793-802.

Chliova, M., J. Brinckmann, and N. Rosenbusch. 2015. "Is Microcredit a Blessing for the Poor? A Meta-Analysis Examining Development Outcomes and Contextual Considerations." Journal of Business Venturing 30: 467-487.

Collins, D., J. Morduch, S. Rutherford, and O. Ruthven. 2009. Portfolios of the Poor: How the World's Poor Live on \$2 a Day. Princeton, NJ: Princeton University Press.

Copestake, J., S. Bhalotra, and S. Johnson. 2001. "Assessing the Impact of Micro-Credit: A Zambia Case Study.” The Journal of Development Studies 37 (4): 81-100.

Corbin, J., and A. Strauss. 2008. Basics of Qualitative Research: Techniques and Procedures for Developing Grounded Theory. Los Angeles, CA: Sage.

Coriat, B., and S. Guennif. 1998. "Self-interest, Trust and Institutions." In Trust and Economic Learning, edited by N. Lazaric and E. H. Lorenz, 48-63. Cheltenham: Elgar.

Corley, G., and A. Gioia. 2004. "Identity Ambiguity and Change in the Wake of a Corporate Spinoff." Administrative Science Quarterly 49: 173-208.

Cumming, D., and J. Suret. 2011. "Entrepreneurial Finance and Venture Capital Markets: Introduction." European Financial Management 17 (3): 420-422. 
Datar, S., M. Epstein, and K. Yuthas. 2008. "In Microfinance, Clients Must Come First.” Stanford Social Innovation Review 1 (6): 38-45.

David, T., and P. Sanyal. 2017. "Associational Participation and Network Expansion: Microcredit Self- Help Groups and PoorWomen's Social Ties in Rural India.” Social Forces 95 (4): 16951724.

de Quidt, J., T. Fetzer, and M. Ghatak. 2016. “Group Lending Without Joint Liability.” Journal of Development Economics 121: 217-236.

Demirguc-Kunt, A., L. Klapper, D. Singer, and P. Oudheusden. 2015. "The Global Findex Database 2014: Measuring Financial Inclusion around the World." Policy Research Working Paper 7255, Washington, DC: World Bank.

Denzin, N., and Y. Lincoln. 2011. "Introduction: The Discipline and Practice of Qualitative Research," In The Sage Handbook of Qualitative Research, edited by N. Denzin and Y. Lincoln, 1-20. Thousand Oaks, CA: Sage.

Du, J., A. Guariglia, and A. Newman. 2015. "Do Social Capital Building Strategies Influence the Financing Behavior of Chinese Private Small and Medium-Sized Enterprises?" Entrepreneurship Theory and Practice 39 (3): 601-631.

Dunn, E., and J. Arbuckle. 2001. The Impacts of Microcredit: A Case Study from Peru. Washington, DC: USAID.

Duvendack, M., R. Palmer-Jones, J. Copestake, L. Hooper, Y. Loke, and N. Rao. 2011. What is the Evidence of the Impact of Microfinance on the Well-Being of Poor People? London: EPPICentre, Social Science Research Unit, Institute of Education, University of London.

Eisenhardt, K. 1989. "Better Stories and Better Constructs: The Case for Rigour and Comparative Logic.” Academy of Management Review 16 (3): 620-627.

Emerson, R. 1962. "Power-Dependence Relations." American Sociological Review 27: 31-41. Ericksen, J., E. Ericksen, and S. Graham. 2014. Over-indebtedness in Mexico: Giving Borrowers a Voice. Washington, DC: FINCA.

Evers, H., and O. Mehmet. 1994. "The Management of Risk: Informal Trade in Indonesia.” World Development 22: 1-9.

Feigenberg, B., E. Field, R. Pande, N. Rigol, and S. Sarkar. 2014. "Do Group Dynamics Influence Social Capital Among Microfinance Clients? Evidence from a Randomized Experiment in Urban India." Journal of Policy Analysis and Management 33 (4): 932-949.

Gao, W., Y. Liu, and L. Qian. 2016. "The Personal Touch of Business Relationship: A Study of the Determinants and Impact of Business Friendship." Asia Pacific Journal of Management 33 (2): 
469-498.

Gedajlovic, E., B. Honig, C. Moore, G. Payne, and M. Wright. 2013. "Social Capital and Entrepreneurship: A Schema and Research Agenda." Entrepreneurship Theory \& Practice 37 (3): 455-478.

Ghatak, M., and T. Guinnane. 1999. "The Economics of Lending with Joint Liability: Theory and Practice." Journal of Development Economics 60: 195-228.

Gin_e, X., and D. Karlan. 2014. "Group Versus Individual Liability: Short and Long-Term Evidence from Philippine Microcredit Lending Groups.” Journal of Development Economics 107: 65-83.

Gironde, C. 2007. “Manque de cr_edit ou manque de profit? L'_economie familiale au Vietnam [Lack of credit or lack of profit? The family economy in Vietnam]." Annuaire suisse de politique de developpement 26 (2): 157-172.

Glaser, B. 1978. Theoretical Sensitivity. Mill Valley, CA: The Sociological Press.

Gonzalez, A. 2008. "Sources of Revenue and Assets Allocation at MFIs." MicroBanking Bulletin 17: 17-24.

Goodman, R. 2017. "Borrowing Money, Exchanging Relationships: Making Microfinance Fit into Local Lives in Kumaon, India.” World Development 93: 362-373.

Granovetter, M. 1973. “The Strength of Weak Ties.” American Journal of Sociology 78 (6): 13601380.

Granovetter, M. 1985. "Economic Action and Social Structure: The Problem of Embeddedness." American Journal of Sociology 91 (3): 481-510.

Granovetter, M. 1992. "Problems of Explanation in Economic Sociology." In Networks and Organizations: Structure, Form and Action, edited by N. Nohria and R. G. Eccles, 25-56. Boston, MA: Harvard Business School Press.

Guerin, I., and S. Kumar. 2017. "Market, Freedom and the Illusions of Microcredit. Patronage, Caste, Class and Patriarchy in Rural South India." The Journal of Development Studies 53 (5): 741-754.

Gu_erin, I., M. Labie, and J.-M. Servet. 2015. The Crises of Microcredit. London: Zed Books. Guerin, I., S. Morvant-Roux, and M. Villarreal. 2013. Microfinance, Indebtedness and Overindebtedness: Juggling with Money. London: Routledge.

Haldar, A., and J. Stiglitz. 2016. "Group Lending, Joint Liability, and Social Capital: Insights from the Indian Microfinance Crisis.” Politics and Society 44 (4): 459-497.

Hossein, C. 2016. Politicized Microfinance: Money, Power, and Violence in the Black Americas. 
Toronto: University of Toronto Press.

IFC (International Finance Corporation). 2014. IFC Microfinance. Washington, DC: IFC.

Jack, S. 2005. "The Role, Use and Activation of Strong and Weak Network Ties: A Qualitative Analysis." Journal of Management Studies 42 (6): 1233-1259.

Jack, S., D. Drakopoulou, and A. Anderson. 2008. "Change and the Development of Entrepreneurial Networks Over Time: A Processual Perspective.” Entrepreneurship \& Regional Development: An International Journal 20 (2): 125-59.

Jonsson, S., and J. Lindbergh. 2013. "The Development of Social Capital and Financing of Entrepreneurial Firms: From Financial Bootstrapping to Bank Funding." Entrepreneurship Theory and Practice 37 (4): 661-686.

Kar, A. 2013. "Double Bottom Lines in Microfinance: Are They Mutually Exclusive?" Journal of Small Business \& Entrepreneurship 26 (1): 87-107.

Karlan, D., and M. Valdivia. 2011. "Impact of Business Training on Microfinance Clients and Institutions." Review of Economics and Statistics 93 (2): 510-527.

Kent, D., and M. T. Dacin. 2013. "Bankers at the Gate: Microfinance and the High Cost of Borrowed Logics." Journal of Business Venturing 28: 759-773.

Khandker, R. 2005. "Microfinance and Poverty: Evidence Using Panel Data from Bangladesh." World Bank Economic Review 19 (2): 263-286.

Khavul, S. 2010. "Microfinancing: Creating Opportunities for the Poor?" Academy of Management Perspectives 24 (3): 58-72.

Khavul, S., H. Chavez, and G. Bruton. 2013. "When Institutional Change Outruns the Change Agent: The Contested Terrain of Entrepreneurial Microfinance for those in Poverty." Journal of Business Venturing 28: 30-50.

Kotir, J., and F. Obeng-Odoom. 2009. "Microfinance and Rural Household Development: A Ghanaian Perspective," Journal of Developing Societies 25 (1): 85-105.

Lee, T. 1999. Using Qualitative Methods in Organizational Research. Thousand Oaks, CA: Sage.

Leinbach, R. 2003. "Small Enterprises, Fungibility and Indonesian Rural Family Livelihood Strategies." Asia Pacific Viewpoint 44 (1): 7-34.

Liao, J., and H. Welsch. 2005. "Roles of Social Capital in Venture Creation: Key Dimensions and Research Implications." Journal of Small Business Management 43 (4): 345-362. 
Mader, P. 2013. "Rise and Fall of Microfinance in India: The Andhra Pradesh Crisis in Perspective." Strategic Change 22 (1-2): 47-66.

Mader, P. 2015. The Political Economy of Microfinance: Financializing Poverty. New York: Palgrave Macmillan.

Mafukata, M., W. Dhlandhlara, and G. Kancheya. 2017. "Reciprocal Relationship of Social Capital and Microfinance Activities in Nyanga, Zimbabwe." Development in Practice 27 (1): $77-$ 89.

McKernan, S. M. 2002. "The Impact of Micro-credit Programs on Self-Employment Profits: Do Non-credit Program Aspects Matter?" The Review of Economics and Statistics 84 (1): 93-115.

Milanov, H., R. Justo, and S. Bradley. 2015. "Making the Most of Group Relationships: The Role of Gender and Boundary Effects inMicrocredit Groups." Journal of Business Venturing 30: 822838.

Moran, P. 2005. "Structural versus Relational Embeddedness: Social Capital and Managerial Performance." Strategic Management Journal 26 (12): 1129-1151.

Moss, T., D. Neubaum, and M. Meyskens. 2015. "The Effect of Virtuous and Entrepreneurial Orientations on Microfinance Lending and Repayment: A Signaling Theory Perspective." Entrepreneurship Theory \& Practice 39 (1): 27-52.

Nahapiet, J., and S. Ghoshal. 1998. "Social Capital, Intellectual Capital and the Organizational Advantage.” Academy of Management Review 23 (2): 242-266.

NIS (National Institute of Statistics). 2015a. National Report on the Millenium Development Goals in 2015. Yaounde: NIS.

NIS (National Institute of Statistics). 2015b. Presentation of the First Results of the Fourth Cameroon Household Survey (ECAM) of 2014. Yaounde: NIS.

Neergard, H., and J. Ulhøi. 2007. Handbook of Qualitative Research Methods in Entrepreneurship. Cheltenham: Edward Elgar.

Newman, A., S. Schwarz, and D. Borgia. 2014. "How does Microfinance Enhance Entrepreneurial Outcomes in Emerging Economies? The Mediating Mechanisms of Psychological and Social Capital.” International Small Business Journal 32 (2): 158-179.

Nooteboom, B. 2002. Trust, Forms, Foundations, Failures and Figures. Cheltenham: Elgar.

Pratt, M. 2009. "From the Editors: for the Lack of a Boilerplate: Tips on Writing up (and Reviewing) Qualitative Research.” Academy of Management Journal 52 (5): 856-862. 
Radhakrishnan, S. 2015. "'Low Profile' or Entrepreneurial? Gender, Class, and Cultural Adaptation in the Global Microfinance Industry." World Development 74: 264-274.

Raihan, R., S. R. Osmani, and M. A. Baqui Khalily. 2017. "The Macro Impact of Microfinance in Bangladesh: A CGE Analysis.” Economic Modelling 62: 1-15.

Ridgeway, C., and L. Smith-Lovin. 1999. “The Gender System and Interaction.” Annual Review of Sociology 25 (1): 191-216.

Rousseau, D., S. Sitkin, R. Burt, and C. Camerer. 1998. "Not So Different After All: A Crossdiscipline View of Trust.” Academy Management Review 23: 393-404.

Rowley, T., D. Behrens, and D. Krackhardt. 2000. "Redundant Governance Structures: An Analysis of Structural and Relational Embeddedness in the Steel and Semiconductor Industries." Strategic Management Journal 21: 369-386.

Sackmann, A. 1991. "Uncovering Culture in Organizations." Journal of Applied Behavioral Science 27 (3): 295-317.

Sanyal, P. 2009. "From Credit to Collective Action: The Role of Microfinance in Promoting Women's Social Capital and Normative Influence.” American Sociological Review 74 (4): 529 550 .

Sanyal, P. 2014. Credit to Capabilities: A Sociological Study of Microcredit Groups in India. New York: Cambridge University Press.

Sayinzoga, A., E. Bulte, and R. Lensink. 2016. "Financial Literacy and Financial Behaviour: Experimental Evidence from Rural Rwanda.” The Economic Journal 126 (594): 1571-1599.

Servet, J.-M. 2006. Banquiers aux pieds nus: La microfinance [Barefoot banker: Microfinance]. Paris: Odile Jacob.

Servet, J.-M. 2015. La vraie r_evolution du microcr_edit [Microcredit's Real Revolution]. Paris: Odile Jacob.

Shahriar, A., S. Schwarz, and A. Newman. 2016. "Profit Orientation of Microfinance Institutions and Provision of Financial Capital to Business Start-ups." International Small Business Journal 34 (4): 532-552.

Shane, S., and S. Venkataraman. 2000. "The Promise of Entrepreneurship as a Field of Research." Academy of Management Review 25: 217-226.

Silverman, D. 2010. Doing Qualitative Research: A Practical Handbook. London: Sage.

Siwale, J. 2016. "Microfinance and Loan Officers' Work Experiences: Perspectives from Zambia." The Journal of Development Studies 52 (9): 1289-1305. 
Skinner, H., G. Moss, and S. Parfitt. 2005. "Nightclubs and Bars: What Do Customers Really Want?” International Journal of Contemporary Hospitality Management 17 (2): 114-124.

Stewart, R., C. Rooyen, K. Dickson, M. Majoro, and T. Wet. 2010. What is the Impact of Microfinance on Poor People? A Systematic Review of Evidence from Sub-Saharan Africa. London: EPPI-Centre, Social Science Research Unit, University of London.

Tang, J. 2010. "How Entrepreneurs Discover Opportunities in China: An Institutional View." Asia Pacific Journal of Management 27 (3): 461-479.

Taylor, M. 2012. "The Antinomies of 'Financial Inclusion': Debt, Distress and the Workings of Indian Microfinance.” Journal of Agrarian Change 12 (4): 601-610.

Taylor, S. J. 1984. Introduction to Qualitative Research Methods. New York, NY: John Wiley. Tubadji, A., K. Kourtit, and P. Nijkamp. 2014. "Social Capital and Local Cultural Milieu for Successful Migrant Entrepreneurship.” Journal of Small Business \& Entrepreneurship 27 (3): $301-$ 322.

Uzzi, B. 1997. "Social Structure and Competition in Interfirm Networks: The Paradox of Embeddedness.” Administrative Science Quarterly 42 (1): 35-67.

Walker, G., B. Kogut, and W. Shan. 1997. "Social Capital, Structural Holes, and the Formation of an Industry Network." Organization Science 8 (2): 109-125.

Wang, C., and H. Chugh. 2014. "Entrepreneurial Learning: Past Research and Future Challenges: Advancing Entrepreneurial Learning Research." International Journal of Management Reviews 16 (1): 24-61.

Wasserman, S., and K. Faust. 1994. Social Network Analysis: Methods and Applications. Cambridge: Cambridge University Press.

Welter, F. 2012. "All You Need is Trust? A Critical Review of the Trust and Entrepreneurship Literature.” International Small Business Journal 30 (3): 193-212.

World Development Indicators. 2015. Washington, DC: World Bank. Accessed 9 February 2017. http://data.worldbank.org/country.

Yu, N. 2008. "Metaphor from Body and Culture.” In The Cambridge Handbook of Metaphor and Thought, edited by R. Gibbs. Cambridge: Cambridge University Press.

Zafar, M., G. Yasin, and M. Ijaz. 2012. "Social Networking a Source for Developing Entrepreneurial Intentions Among Entrepreneurs: A Case of Multan." Asian Economic and Financial Review 2 (8): 1072-1084.

Zhuang, J., H. Gunatilake, Y. Niimi, Muhammad Ehsan Khan, Yi Jiang, Rana Hasan, Niny Khor, 
Anneli S. Lagman-Martin, Pamela Bracey, and Biao Huang. 2009. "Financial Sector Development, Economic Growth and Poverty Reduction: A Literature Review." ADB Economics Working Paper Series No. 173. Manila: Asian Development Bank.

Zozimo, R., S. Jack, and E. Hamilton. 2017. "Entrepreneurial Learning from Observing Role Models." Entrepreneurship and Regional Development 29 (9-10): 889-911. 